2016-2020 roky [National Strategy for Promoting Civil Society Development in Ukraine for 2016-2020]: Ukaz Prezydenta Ukrayiny vid 26 lyutoho 2016 r. Ofitsiynyy visnyk Prezydenta Ukrayiny. 2016. № 7. S. 32. St. 162. [in Ukr.]

23. Pro vnutrishnye ta zovnishnye stanovyshche Ukrayiny v 2012 rotsi [On Internal and External Situation of Ukraine in 2012]: Shchorichne Poslannya Prezydenta Ukrayiny do Verkhovnoyi Rady Ukrayiny. Kyyiv: NISD, 2012. 256 s. [in Ukr.]

\title{
Summary
}

The article deals with the problems of functioning of the political system of society in Ukraine from the standpoint of theoretical and legal science. At the present stage, Ukrainian society is in the active phase of transformation of its political component. This is due to a number of factors, among the leading ones, on the one hand, is the intention to form a democratic, rule of law state, on the other hand - to create a real civil society that will testify to the actual achievement of the provisions of the current Constitution of Ukraine. It is determined that the political system of society is a coherent and complex set of elements, the task of which is aimed at achieving and ensuring the stable functioning of society through their effective interaction and implementation of political functions in accordance with the fundamental principles of law. The features of the political system have been identified. It is emphasised that in Ukraine civil society institutions do not act as full (real) subjects of political and public activity. It is pointed out that the modern political system of Ukrainian society is open and requires communication of its subjects with international partners. It is highlighted that the development of inter-party cooperation at the internal (between national parties) and external (implies two strategic directions: European parties and parties of other democratic states of the world) levels is important. The current political system of Ukrainian society is open and requires communication of its subjects with international partners. The role of the territorial community in the development of the political system of Ukraine is revealed.

Keywords: political system of society, democratic state, civil society, national security, political culture, territorial community.

UDC 342.723

DOI: $10.31733 / 2078-3566-2019-5-66-73$

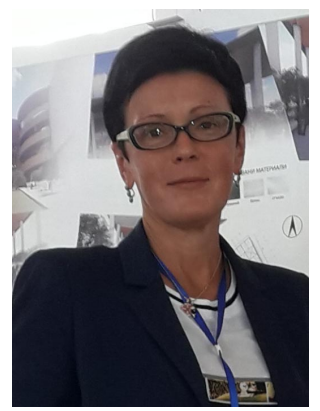

Iryna ALEKSEENKO ${ }^{\odot}$

Dr of Polit. Sciences, Prof.

(Dnipropetrovsk State University

of Internal Affairs)

\section{BIOETHICS IN THE CONTEXT OF MODERN LEGAL DOCTRINE}

Ірина АЛєксєнко. БІОТЕХНОЛОГІЇ В КОНТЕКСТІ СУЧАСНОЇ ЮРИДИЧНОЇ ДОКТРИНИ. Розвиток біотехнологій та впровадження в практику їх досягнень окреслило проблему безпеки здоров'я людини та навколишнього середовища, як складових людської безпеки вцілому. Сьогодні використання на практиці сучасних біотехнологій вимагає належного правового регулювання, адже дана сфера суспільних відносин нова і раніше не регулювалася нормами права. Звертаючись до проблеми правового регулювання біотехнологій, слід брати до уваги не лише позитивні наслідки їх розвитку (боротьба з голодом, захист екології, нові можливості лікування хвороб), а й ризики існуючих численних негативних наслідків використання цих технологій для здоров'я людей і навколишнього середовища.

Більшість дослідників відзначають важливість норм біоетики в регулюванні біотехнологій, що, в свою чергу, породжує труднощі в створенні на міжнародному рівні єдиного правового акта, оскільки принципи біоетики визначаються світоглядом - системою узагальнених знань про об'єктивний світ, ставлення людини до навколишньої дійсності з позиції своїх ідеалів, принципів і переконань. А принципи і переконання унікальні у громадян різних країн.

На думку низки дослідників, характерною особливістю міжнародних правових норм, що регламентують біомедичні відносини, $є$ інтегрованість в них принципів біоетики. Виникнення біоетики і подальша іiі інтеграція в право обумовлені, 3 одного боку, можливістю реалізації досягнень медичної та біологічної науки на практиці, з іншого - наявністю правового вакууму в цій галузі.

(C) Alekseenko I., 2019

ORCID iD: https://orcid.org/0000-0002-6873-003X

irina_alekseenko@yahoo.com 
В юридичній доктрині активно обговорюється роль біоетики в сучасному суспільстві, оскільки право, як інституційний регулятор не може охопити всі суспільні відносини. Зокрема, воно обмежене в можливості вирішувати проблеми регулювання відносин, що виникають при проведенні абортів, трансплантації органів, модифікації ДНК й інших, відносин, пов'язаних із захистом права на життя, здоров'я.

Тому, незважаючи на розходження в думках щодо користі біоетики та ії значущості, принципи біоетики включаються в національні й міжнародні правові акти. При цьому ступінь їх інтегрованості опосередкована сферою застосування біотехнологій i потребує подальших грунтовних наукових викладок.

Ключові слова: біотехнології, генна інженерія, біобезпека, права людини, глобальні проблеми, біоетика.

Problem statement. This article summarizes different points of view in the context of scientific discussion on biosafety and the legal regulation of biotechnology use by states. The legal regulation of biotechnology and nanotechnology, as a rapidly developing branch of science, concerns, first and foremost, activities related to the development, use and transfer of technologies for the use of living organisms. The main purpose of this study is to verificate the need to develop a mechanism that, according to the authors, will be able to implement the state biosafety policy based on the development of certain standards by international organizations and that will serve as a platform for the formation of international biomedical law, through integration principles of bioethics into biomedical relations.

The research object is the rules of international law in the area of international legal regulation of the use of modern biotechnology through the lens of bioethics.

The methodological basis of the research is comparative legal, dialectical, historical legal, comparative, and other research methods.

Results. As a result of the analysis of scientific sources and approaches to solving this problem, evidence of the need for a comprehensive study of the existing scientific array to highlight bioethics has been obtained, and therefore biosafety, as an independent scientific direction in the context of modern legal biotechnology and nanotechnology research and as part of the national security of the state.

In the present conditions, many researchers are of the view that biological weapon represents the type of weapon of mass destruction, whose action is based on the use of the properties of pathogenic microorganisms and their metabolic products of [8].

The revolution that takes place in the field of biotechnology can lead to creating biological weapons, which in terms of affecting parameters are not inferior to nuclear weapon and are more flexible in its application.

Biological weapon because of its combat characteristics, the relative ease of access to its preparation by the terrorist organizations, ease of use, variability of algorithms used to commit acts of biological terrorism and their possible effects acts as the most likely instrument of committing acts of international terrorism among other types of weapons of mass destruction.

It is obvious that biotechnologies have enormous potential and opportunities to influence people and society. However, these perspectives are dual. Noting their scientific and economic significance, it is also necessary to bear in mind their potential threat to man and humanity, in particular, the dangers that may arise with the further penetration of the human mind into the natural forces of nature.

The movement for the protection of human rights that has developed around the world now relies on an extensive system of very diverse international legal agreements relating to the legal status of the individual. The deepening of this process in this area is carried out in several directions. The greatest importance is given to efforts aimed at ensuring the most representative participation of states in agreements on humanitarian issues, including the preservation of biological security on the planet, in order to transform these documents into reliable universal tools for ensuring human rights. Despite the improvement of bioengineering methods, the expansion of the market for biotechnological products, the obvious benefits and efficiency of using environmentally friendly biotechnologies in industry, agriculture and health care, there are still concerns in the society over the possible undesirable consequences for humans of biotechnological production and genetic engineering experiments.

A lot of international bodies that operate under the auspices of the United Nations take the subject of special consideration the protection of the human person in the face of advances in biology, medicine, especially as a result of advances in genetic engineering and biotechnology in general. When creating ever-growing opportunities for improving the living conditions of people, progress in science and technology generate, at the same time, a number of serious 
social problems requiring immediate solutions, including international legal cooperation in ensuring human safety and the environment.

The rapid development of biomedical disciplines significantly affects human rights, such as the right to life, the protection of honor and dignity, health, immunity, and a number of others. Since 1968, the international bodies operating under the auspices of the United Nations have constantly considered questions about the protection of the human personalities, their physical and intellectual integrity in the face of advances in biology, medicine. Since the early 1980 s the similar situation exists in genetic engineering, which is a major component of biotechnology.

However, it is precisely now that fears arise that, in the course of realizing the positive potential of biotechnology and genetic engineering, unintended release of genetically modified organisms and recombinant proteins can occur in laboratories, at work, during field trials; and recombinant products which have not passed the appropriate control and prior approval by the competent authorities can come into the market. Despite the improvement of bioengineering methods, the expansion of the market for biotechnological products, the obvious benefits and efficiency of using environmentally friendly biotechnologies in industry, agriculture and health care, there are still concerns in the society over the possible undesirable consequences for humans of biotechnological production and genetic engineering experiments.

Mastering the methods of genetic engineering and its application leads to creating the new biologically active structures that can not be occur in nature.

In many countries of the world, numerous legislative acts that regulate activities and social relations in the field of genetic engineering are in a force for a relatively long time, while the questions of organization and safety of work with recombinant DNA and the problems of the planned incorporation of genetically modified organisms into the environment are under the attention legal services, scientists and society.

It cover a lot of issues and concerns the cases of loss of control over transformed organisms in the laboratory, production, during field trials; the risk of genetic instability of transgenic plants and animals in a series of subsequent generations and the emergence of unpredictable species of plants and animals; the release of genetically engineered products on the market without proper verification.

These concerns are caused by poor public awareness, imperfect legislation, and insufficient popularization of scientific knowledge among the population. In order to avoid incompetent forecasts and estimates, it is necessary today to bring to the public objective information about the existing balance between the achievements of biotechnology and the risk of genetic consequences; clearly demonstrate whether the danger of specific biotechnologies or experimental areas of bioengineering is real.

Some aspects of the legal regulation of the use of biotechnologies were studied by the following researchers: Beyleveld D., Brownsword R., Feiler W., Ruggiu D., Sasson A., Sedova N., Plomer A. [1-6]

When paying attention to this situation, in this article the authors aim to conduct a retrospective analysis of the legal field of the use of biotechnology, as well as modern political and legal approaches to solving the problem of biosafety in the era of globalization. Due to the incredibly rapid progress of genetic engineering, resulting in relatively short intervals of time to the emergence of completely new levels of knowledge, qualitative and quantitative changes, public policy should be aimed at the constant improvement of legislation on the safety of genetic engineering based on to carry out constant propaganda of knowledge in this area to reduce the unreasonable fears of the population.

Certain contradictions arose between the long-standing norms for ensuring the safety of biological interventions in the environment, human health and the latest advances in science and technology. Therefore, there is a clear evidence of international legal regulation and control over scientific research related in one way or another to a person.

Thus, nowadays the international community has been faced with the task of creating comprehensive guarantees for ensuring the safety of people in conditions of a medical and biological impact on the environment and humans. The importance of the above mentioned issues, as well as the lack of comprehensive researches on this issue, led to the choice of the topic of our scientific article.

Basic content. The legal regulation of biotechnology, a rapidly developing branch of modern science, concerns, first and foremost, the wide range of activity related to the development, use and transfer of technologies for the use of living organisms. 
The twenty-first century is characterized by tremendous discoveries in the field of science and technology, including in the spheres of biology and medicine. Today, new biotechnologies are being developed; they open up new perspectives for people in solving the problems of curability of diseases, extending human life, and solving social problems. Cloning, genetic engineering, reproductive technologies, cellular technologies and other up-to-date technologies globally changed medicine and, thus, initiated the development of certain law standards by international organizations. This process determined the start of the formation of international biomedical law. A characteristic feature of international legal norms that govern biomedical relations is the integration of the principles of bioethics into these international regulations (Beyleveld D., and Brownsword R., 2001).

Emergence of bioethics and its further integration into law is due, on the one hand, to the possibility of realizing the achievements of medical and biological science in practice, on the other hand, the absence of a legal regulation in this area. The legal doctrine actively discusses the role of bioethics in modern society, because the law, as an institutional regulator, cannot cover all social relations. In particular, it is limited in its ability to solve the problems of regulating relations arising during abortions, organ transplantation, DNA modification and other relations related to the protection of the right to life and health.

Traditionally, there are three main models of the relationship between law and bioethics:

- the sociological model, according to which the law is recognized to be incapable of solving ethical problems and, as a result, the standards of bioethics are considered to be the only regulator in the use of biotechnology;

- a formalistic model where the law plays a major role in regulating any biotechnological issues, since the law establishes sanctions for violation of regulatory prescriptions.

Supporter of the formalist model A. Sasson (1987) points out that most international regulations that govern the use of biotechnology, reflect mainly ethical principles. In his opinion, such a mixture of norms of law and ethics creates the threat of legal uncertainty (Sasson A., 1987).

For this reason, it is necessary to rethink the role of ethics in the regulation of biotechnology. It is necessary to define clear boundaries of the legal regulation of biotechnology. D. Ruggiu (2018) takes the similar position. He believes that great amount of blanket law applied to the principles of ethics does not allow increasing the level of legal regulation. This state of affairs makes it difficult to implement the protective function of the law, and in the conditions of a low legal culture of the society, it contributes to the violation of legal regulations; (Ruggiu D., 2018)

- the liberal model, according to which the right confirms only some general bioethical principles. The ideas of the liberal model are presented in the works of N. Sedova (2004). (Sedova N., 2004). The researcher assumes that the principles of bioethics in relation to the of law act as legal custom, and the provisions of the law outline the framework in which the principles of bioethics apply. Plomer A. (2015), emphasizes that the principles of bioethics are a special source of bioethics. Practice shows that despite differences in opinions regarding the benefits of bioethics and its significance, the principles of bioethics are included in national and international legal acts.

Moreover, the degree of their integration is determined by the scope of application of biotechnology. So the cross - boundary move of GMOs is regulated by a universal international legal act such as the Cartagena Protocol. It contains a minimum of references to the principles of bioethics. At the same time, the regulation of biomedical technologies is mainly carried out by the norms of bioethics, since this sphere of social relations objectively cannot be completely regulated by the norms of law.

Discussion. The great importance of bioethics norms while regulating the biotechnology makes difficulties in creating a single legal act at the international level, since the principles of bioethics are determined by the worldview as a system of generalized knowledge of the objective world, people's attitude to the surrounding reality from the standpoint of their ideals, principles and beliefs. But principles and beliefs are various among citizens of different countries.

The need to unify activities in the field of biomedical technologies was the main reason for the adoption of legal acts in the field of bioethics. The first laws were: the Nuremberg Code (August 1947, Nuremberg), the Helsinki Declaration of the World Medical Association "Ethical Principles of Medical Research with Human Participation as a Subject", adopted at the 18th Assembly in 1964,"International Ethical Guidelines for Biomedical Research on Human Beings", adopted by the Council of International Scientific and Medical organizations in 1982 
(amended in 1993 and 2002), and others laws.

At present, only the Nuremberg Code is in force. The regulation of biotechnology is effected by above mentioned international legal acts, such as the "Universal Declaration on the Human Genome and Human Rights" (1997), "the Convention on Human Rights and Biomedicine" (1996).

A number of conventions and international treaties reinforce the common ethical issues of medical research using biotechnology. Among them are: the UN Convention on Human Rights (1989), the Convention on the Prevention and Punishment of the Crime of Genocide (1948), the International Covenant on Human Rights (1966).

The basic biotechnological principles were formulated in 1998 at the IV International Congress on Bioethics, held in Tokyo. They include recognition of the autonomy of the individual, the human right to self-resolution of issues relating to his psyche, emotional status, securing the right to free informed consent; the principle of justice as equal access to social benefits; the fulfillment of the Hippocratic oath and its expansion - not only do no harm, but also do good.

At present, the Universal Declaration on the Human Genome and Human Rights in the CIS enshrined the principle of preventing practices that are contrary to human dignity - prohibiting the practice of cloning for the purpose of reproducing a human individual (Article 11). States are encouraged to take measures at the national level, consistent with the principles outlined in the declaration. However, taking into account that specific obligations are not reflected in the declaration, one can be concluded that the international act is only a recommendation.

A similar principle is confirmed in the UN Declaration on Human Cloning (2005), which is a statement to Member States and contains "a call to ban all forms of human cloning to the extent that they are incompatible with human dignity and protection of human life ..." (A. b). It creates the opportunity for human cloning "to the extent that cloning is compatible with human dignity."[15]

The most important document in the field of regulating biomedical research at the international level is the Council of Europe Convention on the Protection of Human Rights and Dignity in Connection with the Application of Biology and Medicine: Convention on Human Rights and Biomedicine (1997).[10] The document contains the real obligations of states. The Convention calls the priority of the interests and benefits of the individual in comparison with the interests of society and science as the main principle of medical intervention in the human body.

The Model Law "On the Protection of Human Rights and Dignity in Biomedical Research in the CIS Member States"[13], adopted by the Inter-Parliamentary Assembly of the CIS Member States, is in force. The law extends to citizens of states participating in biomedical research and applies to all institutions and individuals involved in conducting this type of research.

According to Article 10 of the Law, all projects involving human biomedical research must undergo an independent ethical review by the ethics committee. Thus, the normative act contains the mechanism of moral evaluation of the technologies being developed before they are put into practice.

The 1994 UN Cairo Convention on Democracy and Development, the World Conference on Women (Beijing, 1995) and other international instruments enshrined a number of reproductive rights, including the right to make decisions regarding the reproduction of offspring, the right to achieve the highest possible level of reproductive health, including through the treatment of infertility.[12]

In the field of assisted reproductive technologies, like other biomedical technologies, there is no single international legal act. It often causes serious problems. As a result, it seems reasonable of adopting a single international law in the field of biotechnology applications (including in the field of assisted reproductive technologies, or at least in the field of legal regulation of surrogate maternity common principles for conducting medical biotechnological research. It will help to solve the problem of controversial situations.

At the 1992 conference in Rio de Janeiro, the countries of the UN recognized the international need for regulating activities related to biotechnology. A committee was created to draft an act, which was later named the Cartagena Protocol. This law is to regulate the issues of protected the move across state borders, the processing, and use of products of modern biotechnology, including organisms modified at the gene level.

Despite the importance of this document, it was signed by only 57 states. In addition to 
the medical field, biotechnology is now widely used in other sectors of the economy. The most significant branches are agriculture, food and pharmaceutical industries.

Since 1996, seeds of genetically modified plants are available for sale. Taking into consideration the solving global food problems in the world, the most significant results in obtaining products using biotechnology, in our opinion, were achieved precisely in the agro-industrial complex (AIC).

Genetically modified fruits and vegetables, legumes have already been represented on world markets. At the same time, there are more and more questions on ensuring environmental and food security, since the consequences of prolonged use of GMOs are not fully understood.

In addition, agricultural crops with new consumer properties, resistant to viruses and parasites, new agricultural plants and animals are being created by using biotechnological developments; genomic certification is being introduced to improve the quality of breeding work. New veterinary biologics are being produced.

Another, no less important area of application of biotechnologies in the agro-industrial complex is the improvement of the feed base for farm animals. Nowadays it is difficult to imagine modern livestock farming without the use of various biologically additives to animal feed and vitamins.

The pharmaceutical industry accounts three quarters of the total sales of a product obtained using biotechnology. It is, above all, the production of drugs and vaccines, diagnostic tools. Thanks to the widespread use of biotechnology in the pharmaceutical industry, a new concept of "personalized medicine" has emerged, when a patient is treated on the basis of his genetic characteristics, including the creation of individual medical products.

Results. The development of biotechnology, the introduction of their achievements into practice has identified the problem of ensuring the safety of human health and the environment. The use of modern biotechnology in practice requires proper legal regulation, because this sphere of social relations is new and not previously regulated by the rules of law. At the same time, it is necessary to take into account not only the positive effects of the development of biotechnologies (combating hunger, protecting the environment, new possibilities for treating diseases), but also all possible risks of the negative consequences of using these technologies on human health and the environment.

Another, no less important area of application of biotechnologies in the agro-industrial complex is the improvement of the feed base for farm animals. Since at present, modern livestock farming is difficult to imagine without the use of various biologically additives to animal feed and vitamins. The pharmaceutical industry accounts for up to of the total sales of a product obtained using biotechnology.

This, above all, the production of drugs and vaccines, diagnostic tools. Thanks to the widespread use of biotechnology in the pharmaceutical industry, a new concept of "personalized medicine" has emerged, when a patient is treated on the basis of his genetic characteristics, including the creation of individual medical products.

The development of biotechnology, the introduction of their achievements into practice has identified the problem of ensuring the safety of human health and the environment. The use of modern biotechnology in practice requires proper legal regulation, because this sphere of social relations is new and not previously regulated by the rules of law.

At the same time, it is necessary to take into account not only the positive effects of the development of biotechnologies (combating hunger, protecting the environment, new possibilities for treating diseases), but also all possible risks of the negative consequences of using these technologies on human health and the environment. Based on the above, legal regimes have the following provisions:

Biotechnology research takes place in two directions: regulatory and protective;

It will be correct to distinguish between legal studies of biotechnology on the basis of the subject (substantive, structural) and functional criteria;

The study of biotechnologies on the basis of the objective criterion (elements of biotechnologies) should be limited to the legal regimes of the regulatory orientation, with emphasis on static patterns, based on the inductive method;

Studies of biotechnology with the application of the law, occur on the basis of functional criteria (scope) require translational and variability in terms of temporal relevance;

It is necessary, on the one hand, to determine the identification of the most significant object elements and process elements (actions) in each individual area of application of bio- 
technology.

And on the other hand, it is necessary to limit the research to the framework that establishes legal norms, protective focus, with the identification of dynamic patterns.

Conclusion. The analysis of the study is resulted into the following conclusions:

First, the analysis of the history of emergence of legal regulation of biotechnologies allows us to conclude that because biotechnologies are understood in a broad sense, and cover many areas of the economy, and there is no clear definition of biotechnologies, it is necessary a multilateral development of legal regulation of the performing and implementation of biotechnologies both into a separate state and into the entire global community.

Secondly, international acts, mainly, are declaratively aimed solely at protective legal regimes (preservation of biological resources), and permits for the use of biotechnologies are simultaneously combined with restrictions and prohibitions.

Ukraine has not acceded to some international regulations governing the use of biotechnology yet. Thus, it is necessary to improve domestic legislation, taking into account international experience in creating a legal framework for regulating the use of biotechnologies in various areas of the economy.

Moreover, the great importance of bioethics while regulating of biotechnology makes difficulties in creating a single legal act at the international level. The principles of bioethics are determined by the worldview as a system of generalized knowledge of the objective world, people's attitude to the surrounding reality from the standpoint of their ideals, principles and beliefs. The principles and beliefs are various among citizens of different countries. Thus, having analyzed the international legal acts that regulate the sphere of biotechnologies, it can be concluded that the international community requires developing cooperation and international relations in this area.

1. Beyleveld D., Brownsword R. Human Dignity in Bioethics and Biolaw, Oxford, Oxford University Press, 2001, 415 p.

2. Feiler W. S. Patent aspects of human cloning in the USA, 1998, vol. 1998. Pp. 20-23.

3. Plomer A. Patents, Human Rights and Access to Science, Cheltenham, Edward Elgar, 2015, 240 p.

4. Ruggiu, D. Human rights and emerging technologies. Analysis and perspectives in Europe, Pan Stanford publishing Pte. Ltd., 2018, 355p.

5. Сассон А. Биотехнология: свершения и надежды. М. : Мир, 1987, 245 с.

6. Седова Н. Н. Правовые основы биоэтики. М. : Триумф, 2004, 287 с.

7. Directive 2001/18/EC of the European Parliament and of the Council of 12 March 2001 on the deliberate release into the environment of genetically modified organisms and repealing Council Directive 90/220/EEC - Commission Declaration. URL: https://eur-lex.europa.eu/legalcontent/EN/TXT/?uri=celex\%3A32001L0018.

8. Universal Declaration on Human Rights (UDHR) adopted in New York on 10 December 1948 by the General Assembly of the United National. URL: https://www.un.org/en/universaldeclaration-human-rights/.

9. Convention on Biological Diversity of de Rio de Janeiro adopted on 5 June 1992.URL:https://treaties.un.org/doc/Publication/MTDSG/Volume\%20II/Chapter\%20XXVII/xxvii-8.en.pdf.

10. Convention on Human Rights and Biomedicine (1997). URL: https://rm.coe.int/168007cf98

11. Universal Declaration on Bioethics and Human Rights, adopted on 19 October 2005. URL: http://portal.unesco.org/en/ev.php-URL_ID=31058\&URL_DO=DO_TOPIC\&URL_SECTION=201.html

12. 1994 Cairo conference prompted «No less then a revolution», population and development commission told. URL: https://www.un.org/press/en/2004/pop897.doc.htm.

13. Модельный закон о защите прав и достоинства человека в биомедицинских исследованиях в государствах-участниках СНГ. URL: https://zakon.rada.gov.ua/laws/show/en/997_d06.

14. Commission Regulation (EC) No 641/2004 of 6 April 2004 on detailed rules for the implementation of Regulation (EC) No 1829/2003 of the European Parliament and of the Council as regards the application for the authorization of new genetically modified food and feed, the notification of existing products and adventitious or technically unavoidable presence of genetically modified material which has benefited from a favorable risk evaluation (Text with EEA relevance). URL: https://publications.europa.eu/en/publication-detail//publication/fda22018-d216-4fcc-9f20-86636149766e.

15. Declaration on Human Cloning adopted on 24 February2005 by the General Assembly of the United National. URL: https://digitallibrary.un.org/record/541409.

Received to editorial office 17.11.2019

1. Beyleveld, D., Brownsword, R. (2001) Human Dignity in Bioethics and Biolaw, Oxford, Oxford University Press, 415 p. [in Eng.] 
Scientific Bulletin of the Dnipropetrovsk State University of Internal Affairs. 2019. Special Issue № 1

2. Feiler, W. S. (1998) Patent aspects of human cloning in the USA, 1998, vol. pp. 20-23. [in Eng.]

3. Plomer, A. (2015) Patents, Human Rights and Access to Science, Cheltenham, Edward Elgar, , 240 p. [in Eng.]

4. Ruggiu, D. (2018) Human rights and emerging technologies. Analysis and perspectives in Europe, Pan Stanford publishing Pte. Ltd , 355p. [in Eng.]

5. Sasson, A. (1987) Biotehnologiya: sversheniya i nadezhdy [Biotechnology: achievements and hopes]. M.: Mir, 245 s. [in Russ.] 287 s. [in Russ.]

6. Sedova, N. N. (2004) Pravovyie osnovyi bioetiki [Legal basis of bioethics]. M. : Triumf,

7. Directive 2001/18/EC of the European Parliament and of the Council of 12 March 2001 on the deliberate release into the environment of genetically modified organisms and repealing Council Directive 90/220/EEC - Commission Declaration. URL: https://eur-lex.europa.eu/legalcontent/EN/TXT/?uri=celex\%3A32001L0018. [in Eng.]

8. Universal Declaration on Human Rights (UDHR) adopted in New York on 10 December 1948 by the General Assembly of the United National. URL: https://www.un.org/en/universaldeclaration-human-rights/. [in Eng.]

9. Convention on Biological Diversity of de Rio de Janeiro adopted on 5 June 1992.URL:https://treaties.un.org/doc/Publication/MTDSG/Volume\%20II/Chapter\%20XXVII/xxvii-8.en.pdf. [in Eng.] [in Eng.]

10. Convention on Human Rights and Biomedicine (1997). URL: https://rm.coe.int/168007cf98

11. Universal Declaration on Bioethics and Human Rights, adopted on 19 October 2005. URL: http://portal.unesco.org/en/ev.php-URL_ID=31058\&URL_DO=DO_TOPIC\&URL_SECTION=201.html [in Eng.]

12. 1994 Cairo conference prompted «No less then a revolution», population and development commission told. URL: https://www.un.org/press/en/2004/pop897.doc.htm. [in Eng.]

13. Modelnyiy zakon o zaschite prav i dostoinstva cheloveka $\mathrm{v}$ biomeditsinskih issledovaniyah v gosudarstvah-uchastnikah SNG [Model Law on the Protection of Human Rights and Dignity of a Person in Biomedical Research in the CIS Member States]. URL: https://zakon.rada.gov.ua/laws/show/en/997_d06. [in Russ.]

14. Commission Regulation (EC) No 641/2004 of 6 April 2004 on detailed rules for the implementation of Regulation (EC) No 1829/2003 of the European Parliament and of the Council as regards the application for the authorization of new genetically modified food and feed, the notification of existing products and adventitious or technically unavoidable presence of genetically modified material which has benefited from a favorable risk evaluation (Text with EEA relevance). URL: https://publications.europa.eu/en/publication-detail//publication/fda22018-d216-4fcc-9f20-86636149766e. [in Eng.]

15. Declaration on Human Cloning adopted on 24 February2005 by the General Assembly of the United National. URL: https://digitallibrary.un.org/record/541409. [in Eng.]

\section{Summary}

The scientific novelty of this study consists in conducting comprehensive comparative analysis of the process of formation of legal norms for the protection of human rights. These norms are contained in existing international agreements on the development of biotechnology, from the point of bioethics as a component of state biosafety. Thus, the practical sphere of implementation of the results of this study is a modern international lawmaking process that must adequately reflect the most important aspects of the application of modern biotechnology by the states of the international community. These important aspects must form the basis of the international biomedical law and the Code of Bioethics. Moreover, the authors make no claims a comprehensive analysis of the problem posed in their work, since many important aspects need further study.

Keywords: biotechnology, genetic engineering, biosafety, human rights, global problem, legal guarantees. 